Вељко Ж. Брборић*

Универзитет у Београду

Филолошки факултет

https://doi.org/10.18485/ai_beckovic.2019.ch17

821.163.41.09 Бећковић М.

$371.3:: 821.163 .41$

\title{
МАТИЈА БЕЋКОВИЋ У НАСТАВНИМ ПРОГРАМИМА И ЧИТАНКАМА ЗА ОСНОВНУ И СРЕДЬУ ШКОЛУ
}

У раду се говори о делу Матије Бећковића у настави. Урађен је увид у актуелне наставне планове и програме за основну и средњу школу и утврђена заступљеност дела М. Бећковића у наставном процесу. Наиме, наставни програм је службени документ и он одређује који писци (и која дела) ће се обрађивати на наставним часовима из књижевности у сваком разреду појединачно. Истовремено су анализиране читанке за основну и средњу школу у којима се говори о делу М. Бећковића, па се тако може видети шта уџбеници доносе и шта се од наших ученика тражи при анализи Бећковићевог дела. Дакле, урадићемо увид у уџбеничку литературу и видети који је избор дела која се обрађују и видети какав је приступ књижевном делу М. Бећковића у нашем образовању. То ће, по нашем мишљењу, бити довољно да се изведу одговарајући закључци о месту и улози дела Матије Бећковића у нашим основним и средњим школама, односно о приступу уџбеничке литературе делу познатог песника.

Кључне речи: Матија Бећковић, наставни програм, читанке, основна школа, средња школа, уџбеници и приручници.

\footnotetext{
* brboricv@eunet.rs

** Рад је резултат истраживања на пројекту Српски језик и юегови ресурси: теорија, опис и примена (бр. 178006), који финансира Министарство просвете, науке и технолошког развоја Републике Србије.
} 


\section{1. Увод}

Један од параметара за вредновање књижевног дела неког писца, не и једини, јесте и тај да ли се он налази у наставном програму и да ли се ученици у школи сусрећу са тим писцем и његовим делом. Реч је о заслуженом признању, тј. стицању титуле школског писца и привилегије да генерације ученика читају његова дела. Разуме се да има писаца са којима се ученици сусрећу само у основној или само у средњој школи, али има и оних писаца са којима се ученици сусрећу и у основној и у средњој школи. Један од таквих стваралаца је и наш познати песник, академик Матија Бећковић.

Било је и дела и писаца који су краће време били у наставном програму, има и оних који су се дуже задржали, постоје и дела која су у наставним програмима више деценија, а нека сигурно и неколико векова. Неспорно је да су наставни програми подложни промени, али промене нису ни тако честе, ни посебно радикалне. Стога је постати школски писац велика част и привилегија.

Када неки писац „уђе” у наставне програме и основну уџбеничку литературу, то истовремено значи да нема ниједног ученика (малолетног грађанина) који се није сусрео са неким књижевним делом и основним биографским подацима тог писца. Познат писац се може бити и без школске учионице, али ово је, ипак, посебно важно за сваког писца, реч је посебном (школском и образовном) вредновању његовог књижевног дела. ${ }^{1}$

Сусрет и упознавање са уметничким текстом у настави претпоставља читав низ радњи, од мотивисања, читања,

1 Истина, у литератури има различитих тумачења. Некада се говори о школским писцима, а некада о школским делима. Нама се чини да ту нема суштинске разлике, ако се изузме чињеница да постоје дела из народне књижевности, без ауторства, док би се у другим могао ставити знак једнакости између школског писца и школског дела. 
доживљавања, проучавања вантекстовних околности, тумачења непознатих речи и израза и све то претходи рецепцији текста и његовој интерпретацији и тумачењу на часу, уз помоћ такозване методичке апаратуре (Павловић 2008: 160).

О појму (термину) школски писаи, литература мало говори, па се може рећи или помислити да се то некако подразумева. Овде издвајамо тумачење Александра Јовановића, јер нам се чини веома јасним и прецизним: „Таутолошки речено, школски писац је писац који је укључен у школски/наставни програм, а ништа мање значајно, и у читанке. Томе треба додати издања лектире, хрестоматије, емисије образовног програма, организоване посете писаца школама, сликовнице за најмлађе итд. Али где престаје важење таутологије, почиње упитаност о садржају и смислу овога појма (...) Међутим одредница школски писаи, или њој одговарајуће одреднице, нема у педагошким лексиконима, нити се о њој пише у методичкој литератури" (Јовановић 2015: 70-71).

У наставним програмима се најчешће уз одређеног писца ставља и конкретно дело, понекад је остављена могућност избора између два или више дела, али постоји и трећа могућност, која се само назначи, а то је избор из његовог књижевног стваралаштва, што је најчешће везано за песнике, а много ређе за прозне писце. У писце, када је реч о избору из књижевног стваралаштва, спада и Матија Бећковић, па се може рећи да је он заступљен делима, а не конкретним делом, да се не обрађује само једном (у једном разреду), већ више пута и да је он писац са којим се сусрећу наши ученици и у основној и у средњој школи. Таквих писаца нема пуно. ${ }^{2}$

2 Сада у Републици Србији пут до наставних програма води преко Завода за унапређивање образовања и васпитања (односно његових комисија), тј. Националног просветног савета (који све то усваја). 


\section{2. Дело Матије Бећковића у школским програмима}

Увидом у наставне планове и програме бивших „истојезичних република” долазимо до (не)очекиваних резултата. О чему се заправо ради? Дело Матије Бећковића заступљено је у Републици Србији и Републици Српској, што је у складу са нашим очекивањима. Наставни програми у Црној Гори немају дело Матије Бећковића, и то је, по нашем мишљењу и неочекивано и неоправдано. У наставним програмима Федерације БиХ и Републике Хрватске нема дела Матије Бећковића, и то сазнање није неочекивано. ${ }^{4}$

Иначе, у званичним програмима у Црној Гори, поред неспорних писаца има места за дела следећих аутора: Сретена Асановића, Вељка Радовића, Вељка Мандића, Јеврема Брковића, Радована Зоговића, Јанка Ђоновића, Младена Ломпара, Сретена Перовића, Хусеина Башића, Виту Николића, Ћамила Сијарића, Драгана Николића, Николу Лопичића, Ристу Ратковића, Александра Ивановића, Мирка Бањевца, Мусу Ћазима Жатића, Балшу Брковића, Огњена Спахића, Зувдију Хоџића... Није нам намера да оспоравамо било кога од поменутих писаца и њихових дела, али не можемо да се не запитамо како у школ-

3 О наставним програмима доста је писано у релевантној методичкој литератури (Николић: 1992, Илић: 1997, Маринковић 2003, Милатовић 2011).

4 О овоме се нећемо посебно бавити у раду, мада остаје отворено питање како у Црној Гори нема места за М. Бећковића, посебно ако знамо да му је званична Црна Гора доделила Његошеву награду, и то још пре двадесетак година, и да му је награду уручио актуелни председник Мило Ђукановић, рекавши: „Црне Горе нема без слободе, Бећковићево песничко дело, естетски мерено и измерено, уврстило се у свевремене споменике таквој, слободној Црној Гори. Тиме је досегло достојност Његоша и имена на Биљарди на Цетињу." Сматрамо да овај цитат довољно говори и да је сваки коментар сувишан. 
ском систему Црне Горе нема места за Матију Бећковића, односно за избор из његовог књижевног стваралаштва.

Увидом у наставни програм Републике Српске у деветом разреду основне школе налазимо Избор из савремене српске кюижевности, и то отвара могућност да се ученици основне школе (девети разред) упознају са животом и делом М. Бећковића. У четвртом разреду средњих стручних школа и гимназија налазимо такође Избор из савремене српске кюижевности. Овде се помиње шест писаца, међу њима је и М. Бећковић (поред Б. Пекића, Б. Шћепановића, М. Булатовића, Р. П. Нога и Ђ. Сладоја). С друге стране, у свим четворогодишњим стручним школама, у четвртом разреду уз одредницу савремена книжевност налази се име Матије Бећковића и наслов поеме „Вера Павладољска".

Наставни програми у Републици Србији допуштају да се ученици са М. Бећковићем сусрећу у осмом разреду, а у средњој школи је то обавезно у четвртом разреду, уз отворену могућност да то буде и у првом разреду. Заправо, у осмом разреду се доноси допунски избор текстова, и међу њима је и „Прича о Светом Сави” Матије Бећковића, али пошто за сва наведена дела нема места, може се рећи да Бећковић није обавезан. Ипак, по нашим сазнањима, и у осмом разреду, када је посреди реализација, М. Бећковић се редовно обрађује на наставним часовима.

У првом разреду средње школе сусрећемо Избор из поезије савремених српских писаца према избору ученика и наставника, нема директно Бећковићевог имена, а има Д. Радовића, М. Антића и Љ. Симовића, мада јасно стоји „и други”. То оставља могућност да обрада Бећковићевог дела у првом разреду средње школе зависи од избора предметних наставника. У четвртом разреду средње школе сусрећемо Избор из савремене српске књижевно$c m u$, и ту је наведено име М. Бећковића, па можемо устврдити да је он обавезан писац за све наше матуранте, 
без обзира на то да ли су ученици гимназије или четворогодишњих стручних школа.

\section{3. Дело Матије Бећковића у читанкама}

Читанка је традиционалан уџбеник у настави књижевности, окупља књижевне текстове као примарне и секундарне изворе за проучавање текстова (илустрације, фотографије, репродукције, цртеже), као и информације о писцима, књижевнотеоријским и функционалним појмовима, али и питања и објашњења за тумачење сваког књижевног текста (Павловић 2008: 161). Како бисмо дошли до поузданих података о заступљености дела М. Бећковића у уџбеницима за основну и средњу школу, одлучили смо да консултујемо девет уџбеника (читанки). Консултовали смо три читанке за осми разред основне школе и по три читанке за први и четврти разред средње школе. Ево списка консултованих читанки: ${ }^{5}$

1. Љиљана Бајић, Зона Мркаљ, Читанка за 8. разред основне школе, Завод за уџбенике.

2. Зорица Несторовић, Златко Грушановић, Читанка за 8. разред основне школе, Клет.

3. Наташа Станковић Шошо, Читанка за осми разред основне школе, Логос.

4. Љиљана Николић, Босиљка Милић, Читанка са кюижевнотеоријским појмовима за I разред средюе школе, Завод за уџбенике.

5 Одлучили смо се за ових девет уџбеника из следећих разлога. Наиме, Завод за уџбенике има дугу традицију издавања школских књига, деценијама је био и једини издавач школских књига у Србији. Издавачка кућа Клет наметнула се у последњих десетак година као издавач који је најзаступљенији када је посреди наш предмет, али смо хтели консултовати и друге издаваче Логос и Бигз, сматрајући да је ово најрепрезентативнији увид у наше читанке за поменуте разреде. 
5. Босиљка Милић, Катарина Вучић, Читанка са книжевнотеоријским појмовима за I разред гимназија и средюих стручних школа, Завод за уџбенике.

6. Душко Бабић, Читанка за први разред средюе школе, БИГЗ. 7. Љиљана Николић, Босиљка Милић, Читанка са книжевнотеоријским појмовима за IV разред средње школе, Завод за уџбенике.

8. Љиљана Бајић, Миодраг Павловић, Зона Мркаљ,Читанка за четврти разред гимназија и средних стручних школа, Клет.

9. Предраг Петровић, Мина Ђурић, Бошко Сувајџић, Наташа Станковић Шошо, Читанка за четврти разред гимназија и средних стручних школа, Логос. ${ }^{6}$

\section{4. Биографија Матије Бећковића у читанкама}

Читанка за 8. разред основне школе Завода за уџбенике доноси доста података о писцу: „Бећковић, Матија (Сента, 1939), академик, један од најпознатијих и међу читаоцима најомиљенијих савремених српских песника. Његови књижевни почеци протичу у знаку час бунтовне, час меланхоличне лирике. У зрелој фази свога рада Бећковић се окреће поезији писаној на ровачком говору, у којој на маестралан начин укршта патетичну и комичну димензију живота; том поезијом он привлачи пажњу и изузетно интересовање и публике и критике. У новијим

6 Иако није био планиран наставним програмом за шести разред основне школе, читанка Завода за уџбенике, чији је аутор Милка Андрић, са поднасловом „У памћење су ушли из поезије” налазимо одломак из књиге Косово - најскупља српска реч Матије Бећковића. Поменути одломак је био у функцији тумачења неких епских народних песама о Косовском боју, јунаштву и родољубљу наших предака. После одломка следиле су песме „Молитва” Милутина Бојића, „Нејаки Ненаде” Драгољуба Филиповића и Вече Ђуре Јакшића. Ово је била прилика да се и ученици шестог разреда упознају са делом М. Бећковића. 
етапама свога рада Бећковић пише песме-коментаре који у себи носе меланхолично-лирску визију песниковог почетка и епски профилисану мисаоност његове ровачке фазе. Најпознатија дела: Вера Павладолька, Метак луталииа, Тако је говорио Матија, Рече ми један чо 'ек, Међа Вука Манитога, Леле и куку, Кажа, Чији си ти мали, Ћераћемо се још, Хлеба и језика, Сабране песме I-VIII (2004)" (Бајић и Мркаљ 2006: 218).

Читанка за 8. разред издавачке куће Клет, са поднасловом „Представљамо ти...”, о М. Бећковићу доноси следеће податке: „Рођен 1939. године у Сенти. Након завршетка Филолошког факултета у Београду радио је као новинар. Посветио се писању есеја и поезије. Члан је Српске академије наука и уметности. Живи и ради у Београду. Један је од најпознатијих савремених српских песника. Његови стихови су препознатљиви по оштрини речи и духовитости. Често користи дијалектизме. Најпознатије збирке песама су Вера Павладолька, Метак Луталииа, Тако је говорио Матија, Ћераћемо се још, а есеји Служба Светом Сави, О Његошу и Косово најскупља српска реч" (Несторовић и Грушановић 2016: 38). ${ }^{7}$

Трећа консултована Читанка за осми разред, издавачке куће Логос, о Матији Бећковићу доноси мало података: „Матија Бећковић (1939, Сента), савремени српски песник и академик. Најпознатија дела: Вера Павладолька, Метак Луталииа, Тако је говорио Матија, Рече ми један чоек, Међа Вука Манитога, Леле и куку, Кажа, Чији си ти мали, Ћераћемо се још, Хлеба и језика.

7 Овде у биографији стоји реченица: „Након завршетка Филолошког факултета у Београду радио је као новинар.” Није нам јасно како је дошло до овог пропуста, тј. нетачног податка. Наиме, М. Бећковић није завршио Филолошки факултет. Уз то, М. Бећковић се није претерано бавио новинарством, па не видимо разлог да се то посебно истиче. 
Живи и ствара у Београду" (Станковић Шошо 2016: 176). ${ }^{8}$

Ранија Читанка за први разред средне школе Завода за уџбенике није имала уврштено ниједно дело Матије Бећковића, док Читанка која се појавила 2016. године (прво издање) и коју као аутори потписују Босиљка Милић и Катарина Вучић у одељку „Избор из поезије савремених српских писаца" доноси две песме М. Бећковића и ове податке о њему: „Матија Бећковић (1939). Савремени писац, песник љубавне лирике и поема. После завршеног Филолошког факултета, радио је као новинар. Посветио се писању есеја и поезије. Члан је Српске академије наука и уметности. Један је од најпознатијих савремених српских песника. Његови стихови су препознатљиви по оштрини речи и духовитости. Користи и дијалектизме. За књижевни рад добио је многа признања. Живи и ради у Београду. Најпознатије збирке песама: Вера Павладољска (1962), Метак Луталица (1963), Тако је говорио Матија (1965), Ћераћемо се јом (1996), Хлеба и језика (1997); познатији есеји: Служба Светом Сави, О Његошу и Косово, најскупља српска реч" (Милић, Вучић 2016: 128). ${ }^{9}$

8 Не можемо а да не приметимо да Читанка за осми разред издавачке куће Клет о Матији Бећковићу говори само у четири реда текста, а да иста читанка о неким другим писцима доноси неупоредиво више података. Истовремено се о Љубомиру Симовићу говори на 14 редова текста, Браниславу Нушићу на 19 редова, а више података од М. Бећковића налазимо о Јасминки Петровић, Милету Недељковићу, Ђури Јакшићу, Оскару Давичу, Љубомиру Ненадовићу, Молијеру, Рилкеу, Петрарки, Бориславу Михајловићу Михизу. Тако се о Михајлу Пантићу говори на девет редова, о Бошку Сувајџићу на седам редова, иако су њихова дела дата по избору. Овакав приступ нам није близак и ово не можемо разумети. У неким уџбеницима се дело Метак луталица пише у нескладу са правописом, па налазимо Метак Луталица.

9 И овде сусрећемо нетачан податак о завршетку Филолошког факулета, тј. понављање раније уоченог пропуста. 
Читанка за четврти разред средне школе Завода за уџбенике не доноси податке о М. Бећковићу. Разлог видимо у томе што је он уврштен у први разред овог издавача, па су аутори хтели избећи понављање. Остаје отворено питање да ли је оправдано да неке читанке у оквиру избора из савремене српске кюижевности, која се јавља и у првом и у четвртом разреду, поступају различито. Наиме, неке Бећковића доносе у првом, а неке у четвртом разреду. Нама се чини да је боље да се M. Бећковић изучава у четвртом разреду средњих школа.

Читанка за четврти разред средюе школе издавачке куће Клет доноси доста података о писцу: „Матија Бећковић (1939) велики српски песник, рођен у Сенти. Ниже разреде гимназије похађао је у Колашину и Славонском Броду, а вишу гимназију у Ваљеву. Завршио је Филолошки факултет у Београду. Прву песму штампао је као гимназијалац 1957. у Младој култури. За редовног члана САНУ изабран је 1991. Бећковићеви прозни и поетски текстови приређивани су за позориште и извођени на домаћим и страним сценама. Заједно са Бориславом Михајловићем Михизом адаптирао је Његошев Горски вијенац, а представа је изведена на сцени Народног позоришта у Београду 1980. Приредио је за штампу и две књиге Симе Милутиновића Сарајлије. За своје песништво добио је бројне награде, а најзначајнија дела су му: Вера Павладолька, Метак луталица, Тако је говорио Матија, О међувремену, Че, трагедија која траје, Рече ми један чоек, Међа Вука Манитога, Леле и куку, Служба Светом Сави, О Његошу, итд." (Бајић и др. 2016: $377-378) .^{10}$

10 Понавља се нетачан податак о Бећковићевом образовању и не можемо да нађемо оправдање за овакав пропуст. Дакле, сваки трећи уџбеник (читанка) погрешно информише ученике о академском образовању М. Бећковића. Реч је о лако проверљивом податку, па ову врсту непажње сматрамо недопустивом у уџбеницима. 
Трећи консултовани уџбеник за матуранте је уџбеник издавачке куће Логос и њега као аутори потписују Предраг Петровић, Мина Ђурић, Бошко Сувајџић, Наташа Станковић Шошо. Подаци о писцу нису опширни: „Матија Бећковић (1939), српски песник и драмски писац, рођен у Сенти. Студирао је књижевност на Филолошком факултету у Београду. Пише поезију, поеме и драме. Редован члан САНУ. Објавио је поему Вера Павладолька (1962), те збирке песама и поеме Метак луталица (1963), Тако је говорио Матија (1965), Рече ми један чоек (1970), Међа Вука Манитога (1976), Леле и куку (1980), Поеме (1983), Кажа (1988), Ћераћемо се јом (1996), Кад будем млађи (2007) и др." (Петровић и др. 2016: 370).

Наведени подаци сведоче о врло неуједначеном приступу животу и делу нашег песника, али о томе ће касније бити више речи.

\section{5. Илустрације у читанкама}

У неким уџбеницима сусрећемо врло успешне илустрације. Тако у Логосовом уџбенику за осми разред сусрећемо две одличне илустрације, једна је Светог Саве (стр. 174), а друга Храма Светог Саве на Врачару (стр. 176), њих сусрећемо уз „Причу о Светом Сави” и мислимо да су у функцији тумачења текста. Ево тих илустрација. 

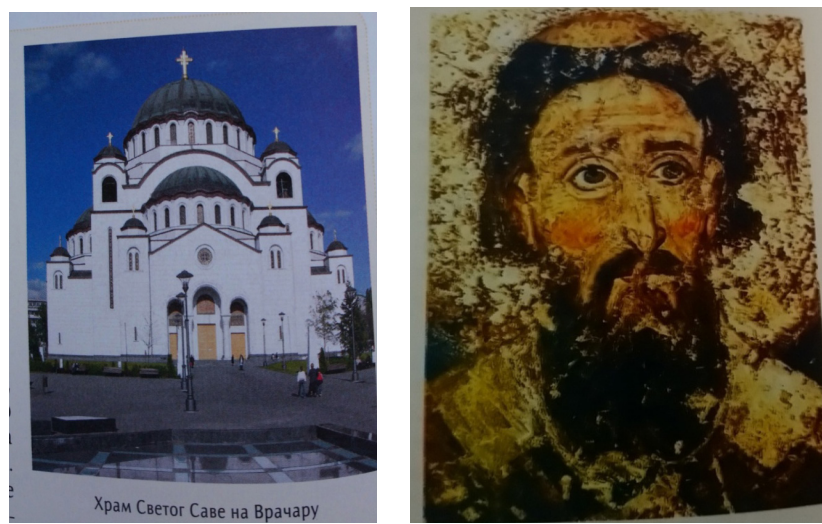

Илустрације бр. 1: Логосова Читанка за осми разре

У уџбенику издавачке куће Клет за осми разред сусрећемо уз песму „Прича о Светом Сави” одличну репродукцију (фотографију) фреске из манастира Студеница (Илустрације бр. 2), али и, по нашем мишљењу, посве неуспешну илустрацију на којој је дат неки цртеж Светог Саве са вуковима. И поред објашњења да су Светог Саву звали „вучјим пастиром” ова илустрација делује као промашај (Илустрације бр. 2).
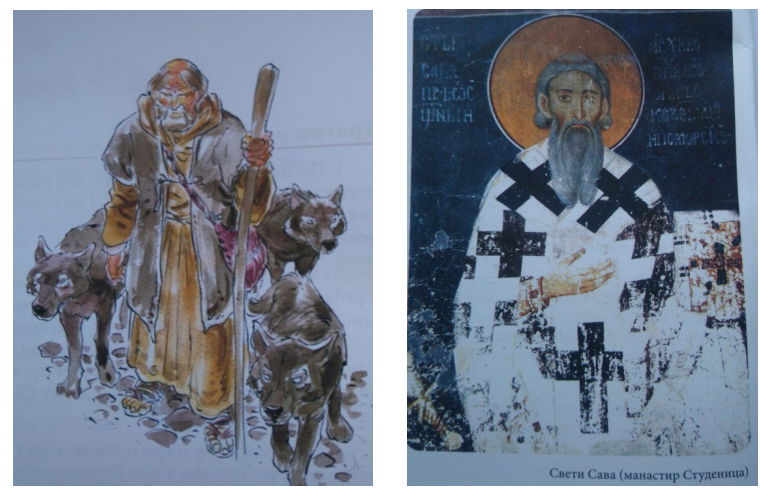

Илустрације бр. 2: Клетова Читанке за осми разред 
Међутим, сусрећемо и илустрације које нам делују крајње необично и не видимо њихову повезаност са Бећковићевим стиховима. Тако у уџбенику Логоса за четврти разред, уз Бећковићев одломак из поеме „Кад дођеш у било који град” сусрећемо фотографије уметничких слика Милана Туцовића („Изгубљени град” и „Чекање”) и Леонида Шејке („Калемегданска тераса”), а није нам јасан разлог због чега се оне ту налазе.
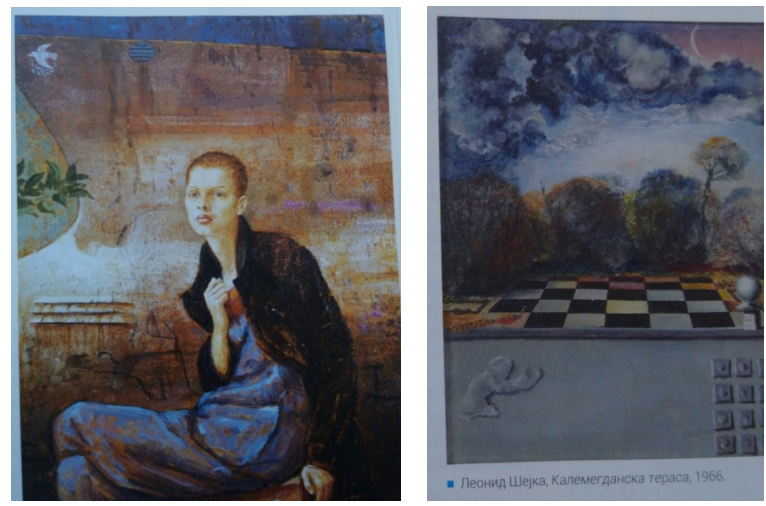

Илустрације бр. 3: Логосова Читанка за четврти разред

Ако се осврнемо на илустрације из три читанке, можемо лако закључити да су неке од њих врло коректне и да су у функцији тумачења књижевног дела. Такав је случај са Логосовом Читанком за осми разред (Илустрације бр. 1). У Клетовој Читанци за четврти разред имамо једну неуспешну и једну успешну илустрацију (Илустрације бр. 2). Чак ни објашњење уз поменуту илустрацију није најсрећније: „Због тога су неки од њега очекивали помоћ, а неки су страховали. Највише су га се плашили сточари. Сматрали су да је он господар вукова и зато су Светог Саву звали вучјим пастиром, а вукове Савиним керовима или Савиним хртовима" (Несторовић, Гру- 
шановић 2016: 38). Прва репродукција, фреска Светог Саве из манастира Студеница, врло је илустративна, док је друга, уз објашњење текста „Прича о Светом Сави”, могла бити успешнија.

Илустрације из Логосове Читанке за четврти разред нису нам јасне. Уз Бећковићеве стихове (одломке) из поеме Кад дођеш у било који град налазе се фотографије три уметничке слике. Две су Милана Туцовића: „Изгубљени град” (1996) и „Чекање” (2006), и Леонида Шејке „Калемегданска тераса” (1966), и њих не видимо у функцији тумачења Бећковићевих стихова.

Неке од поменутих читанки немају илустрације уз Бећковићеве стихове и то не сматрамо пропустом, посебно не у средњој школи. Истина, уколико илустрације постоје, убеђени смо да оне морају бити у функцији тумачења стихова, иначе не видимо сврху њиховог доношења.

\section{6. Избор текстова и њихово тумачење}

Читанка за осми разред основне школе Завода за уџбенике доноси текст „Прича о Светом Сави”. После песме сусрећемо објашњење две мање познате речи (синцир и продол), уз два „блока питања” која су у функцији тумачења текста (Бајић, Мркаљ 2006: 123-124). Овом тексту претходи одломак из Теодосијевог Житија Светом Сави, па је то прилика да ученици боље упознају живот и дело Светог Саве.

Читанка Клета такође доноси песму „Прича о Светом Сави”, уз текст је дато објашњење пет мање познатих речи (доцније, синцир, продол, узмаћи и студен). ${ }^{11}$ Следе

11 Више пута смо истицали да је објашњење непознатих речи и израза врло важно за добро тумачење књижевног текста (Брборић 2018). То посебно долази до изражаја у песмама М. Бећковића, у којима за ученике има доста мање познатих речи. 
питања и објашњења за тумачење песме, па можемо издвојити део који објашњава значај легенде: „По начину на који почиње, ова песма подсећа и на неку легенду. Издвој јунака ове песме и наведи догађаје у којима он учествује. Одреди временске и просторне одреднице тих догађаја. Присети се предања о Светом Сави..." (Несторовић, Грушановић 2016: 37). После питања сусрећемо добро одабрану географску карту, насловљену „Топоними у вези са именом Свети Сава” (детаљ). Ту су означени бројни топоними са Савиним именом: Савин лакат, Савин кук, Савина вода, Савино камене, Савина глава, Савинац, Савина вода..., што може деловати и информативно и инспиративно. Пријемчиво делује и објашњење изреке Гора је рана од језика негли од мача из књиге Фразеологија и национална култура Драгане Мршевић Радовић.

И Логосова Читанка за осми разред доноси текст „Прича о Светом Сави”, са објашњењем мање познатих речи (синиир, продол) и три блока питања и тумачења текста: „Разговор о књижевном тексту”, „Мали Ђачки подсетник” (сусрећемо објашњење шта је предане), „Занимљивост”. Уз коректна питања и запажања сусрећемо и цитат Владимира Ћоровића, „Свети Сава у народном предању", а реч је о спаљивању моштију Светог Саве и то је свакако добро подсећање на сву трагику наше прошлости.

Радује усклађеност све три консултоване читанке за осми разред. Све доносе песму „Прича о Светом Сави”. У сваком уџбенику имамо објашњење неколико непознатих речи, а објашњења и задаци уз текст могу се окарактерисати као успешни.

Већ смо констатовали да ранија Читанка Завода и актуелна Читанка Бигза за први разред немају у свом избору ништа од дела М. Бећковића, док актуелна Читанка за први разред гимназија и средних стручних 
школа Завода за уџбенике доноси одломке из поема Вера Павладолска и Ниси ти више мали (Милић, Вучић 2016: 128-130). После одломака сусрећемо коректно урађену табелу са поделом ауторске књижевности. Ово је насловљено као „Систематизација” и после следи шеснаест питања с поднасловом „Проверите знање”. Бећковићеве песме су овде уз песме Љубомира Симовића и Мирослава Антића у оквиру поглавља „Избор из поезије савремених српских писаца", али нам се чини да су питања и објашњења могла бити одвојена за сваког писца и њихове песме. Пре песама се налази коректно објашњење са захтевом за ученике: „Савремена књижевност обухвата књижевна дела која су настала у другој половини ХХ и у првим деценијама XXI века. Избором савремених песама завршава се прво поглавље у овом уџбенику, које доноси усвајања значајних теоријских законитости, сазнање о природи и смислу књижевности и особености књижевног дела као уметности. Избор из поезије савремених песника пружа прилику да се на крају поглавља 'Увод у проучавање књижевног дела' уђе у сасвим самостално истраживачко читање и доживљавање савремене поезије. У избору представника наше савремене књижевности и њихових песама уочићете разнолику тематику, мотиве и песничку форму. Начините свој приступ песмама и припремите се да их на часу самостално интерпретирате” (Милић, Вучић 2016: 126). ${ }^{12}$ Дакле, од три консултоване читанке за први разред средњих школа само она Завода

12 Приспуп за слободан избор песама је само делимично оправдан. Нама се чини да би било боље да се обрађује једна песма или један одломак из поеме и да то буде за све ученике, а да се после тога може оставити наставницима и ученицима да направе слободан избор. Тако бисмо били у прилици да се сви ученици упознају са неким стиховима и да то буде обавезно, а други део би им дао пуну слободу, код додатног избора песама или стихова. 
за уџбенике доноси Бећковићева дела, док читанка Бигза и ранија читанка Завода немају уврштене Бећковићеве песме у свој садржај.

С обзиром на то да је Заводова читанка у првом разреду доносила Бећковићеве песме, очекивано је да их нема у четвртом разреду. Тако се уџбенички несклад из првог разреда средњих школа проширио и на четврти разред средњих школа.

Клетова Читанка за четврти разред гимназија и средюих стручних школа, уз фотографију М. Бећковића доноси занимљив цитат самог писца: „Као песник родио сам се у Ваљеву пре 40 година. Вера Павладољска је моја прва поема и моја прва љубав. И не знам баш много оних који су се оженили својом првом љубављу. Помешали су се и живот и поезија. А поезија је мој живот, и моја прва и последња љубав" (Бајић и др. 2016: 368). После тога сусрећемо одломак из поеме Вера Павладольска, песму „Богородица Тројеручица”, написану у манастиру Хиландар 1976. године и одломак из поеме „Кад будем млађи" (Бајић и др. 2016: 368-370). После Бећковићевих стихова налазе се питања за ученике и од њих се очекује да открију стваралачке могућности језика у поезији М. Бећковића, да одаберу једну од песама понуђених у уџбенику и да одреде различите појмове који су асоцијативно повезани. Задатак за ученике је и да открију различита осећања у свету стихова и да тумаче смисао исказаних стихова (Бајић и др. 2016: 370). ${ }^{13}$

13 Стиховима претходи и одломак из беседе Јована Делића, којом је образложена додела награде Печат времена М. Бећковићу. Ево дела тога образложења: „Име Матија постало је печат којим се више од пола вијека овјерава суво злато српске поезије. Није га дао ни кум, ни отац, нити је поновљено предачко име, већ га је Бећковић младенац својевремено донео рођењем, као зрак онога свијета на овоме. Родио се на Дан Светог апостола и јеванђелисте Матеја, а његово рођење и име благовијестили 
Читанка за четврти разред издавачке куће Логос доноси одломак из поеме „Кад дођеш у било који град”, а одломку претходи објашњење Јована Делића: „Ово је поема о љубави - вољеној, изгубљеној жени, Вери Павладољској - али и о смрти, односно о Богу, који се у поеми готово и не помиње, али је непрестано присутан. Као гаранција универзалних закона, као твораца чуда, а чудо је пут сваког човјека који исписује његов живот, пут који се непрестано понавља, а који је у сваком конкретном случају непоновљив. (...) Лична љубавна прича тако постаје општа прича, па је и по том што је прича, и по томе што је општа прича, и по томе што је прича о догађају који се понавља, мада на нов начин, добила својство мита" (Петровић и др. 2016: 365). Одломак доноси више од 220 стихова, овде је дат на пет страна и после њега сусрећемо три блока питања и, чини се, важно објашњење: „Песма Вера Павладолска испевана је 1960. године, у време младићке заљубљености, а поема Кад дођеш у било који град настала је 1999. године, непосредно по њеној смрти" (Петровић и др. 2016: 370).

Приступ поезији М. Бећковића неуједначен је у четвртом разреду средње школе. О чему је заправо реч? Читанка Завода за уџбенике не доноси избор из Бећковићеве поезије, јер је то урађено у уџбенику за први разред. Клетова Читанка доноси одломак из поеме Вера Павладољька и одломак из поеме Кад будем млађи и песму Богородица Тројеручиияа, док Логосова Читанка доноси одломак из поеме Кад дођеш у било који град. Овакав приступ, са слободним избором, отежава посао наставницима и доводи до тога да наши матуранти имају неуједначен увид у Бећковићево дело и неуједна-

су мајци рука и глас њенога раноупокојенога брата, који је, у сестрином сну, ставио руку на стомак Матијине мајке да би је заштитио од крвничког ножа, уз узвик: 'Не, ту је Матија"' (Бајић и др. 2016: 368). 
чено знање о вредности поезије М. Бећковића и њеном месту у српској књижевности на крају XX и почетку XIX века. Остаје могућност да неуједначеност исправе предметни наставници на часовима књижевности и да наши ученици, на тај начин, имају боља сазнања о вредности књижевног стваралаштва М. Бећковића.

\section{7. Закључна размишљања}

Књижевно дело Матије Бећковића уврштено је у наставне програме и за основну и за средњу школу у Републици Србији. Истина, избор дела није увек јасно дефинисан. Тако се у осмом разреду обрађује „Прича о Светом Сави”, док се у средњој школи, по избору аутора уџбеника (и издавача), Бећковић обрађује у четвртом разреду, али се може срести и у првом разреду. Избор текстова није уједначен. Најчешћи је одломак из поеме „Вера Павладољска”, али сусрећемо и друге стихове: Кад дођеш у било који град (одломак), „Богородица Тројеручица”, и одломак из поеме Кад будем млађи. Овакав приступ аутора уџбеника може имати и предности и слабости.

У свим консултованим читанкама, где су уврштени текстови М. Бећковића, налазе се основни подаци о животу и делу М. Бећковића. Ипак, ти подаци су у нескладу са његовим делом и појављују се три проблема. Први се огледа у томе што је очигледан несклад између уџбеника за основну и средњу школу. Ако пажљиво погледамо те податке, видећемо да су они исцрпнији у основној него у средњој школи, и ту видимо пропуст у уџбеницима. Не можемо разумети као се у три читанке налазе погрешни подаци о Бећковићевом образовању и овакав пропуст иде „на душу” и аутора и рецензената и издавачких кућа. Такође се може констатовати да је неуједначен приступ Бећковићевим делима и да, 
по правилу, недостају новија књижевна остварења, иако је већина консултованих читанки из 2016. године. О животу и делу Матије Бећковића постоји сасвим доста података и овакви превиди се тешко могу оправдати. Најпрецизније податке можемо наћи у монографији Антологија Бећковић. ${ }^{14}$

Може се рећи и да је неуједначен приступ избору Бећковићевих стихова. Само у једном уџбенику сусрели смо прозни текст „У памћење су ушли из поезије”, реч је о одломку из књиге записа Косово - најскупља српска реч. Што се тиче консултованих читанки за осми разред, свака доноси песму „Прича о Светом Сави”, и то се може сматрати оправданим и добрим поступком. Наставни програми за средњу школу и у првом и у четвртом разреду нуде Избор из савремене српске книжевности и то је отворило неку врсту проблема. Неки аутори и издавачи су се определили да избор из Бећковићеве поезије доносе у првом, а неки у четвртом разреду средње школе.

Други потенцијални проблем је што сусрећемо различит избор из Бећковићеве поезије, и то се може двојако тумачити. Прво је да се дозвољава слобода и ауторима и наставницима, па се ученици сусрећу са различитим избором, али то истовремено значи и да се на такмичењима и пријемним испитима не могу постављати питања из Бећковићеве поезије, јер не можете знати које су текстове и у ком разреду ученици обрађивали.

Волели бисмо да се у читанкама нађе и нека од беседа

14 У свакој од објављених књига Матије Бећковића, по правилу, може се наћи белешка о писцу. Ми смо за ове податке користили књигу 100 мојих портрета, која је из 2018. године, и прецизни подаци о животу и делу писца налазе се на четири стране (Бећковић 2018: 269-272). За избор поезије врло је добра поменута Антологија Бећковић, а избор и поговор ове антологије сачинио је Селимир Радуловић. Издали су је Православна реч и Orpheus 2009. године. 
Матије Бећковића. Радо бисмо кандидовали „Службу Светом Сави”. Ево једног цитата из те беседе: „Подижемо највећу богомољу кад нам је најтања вера. Подиже је одбожено покољење, у једно безбожно време. У недоба које је веровало да ни старе цркве ничему неће служити, а било сигурно да нове неће градити. (...) Гологлави Београд добија капу, и на капи крст, који се, већ причају, види из Софије” (Бећковић 2000). ${ }^{15}$

Било би добро да се на наставним часовима разговара и о језику М. Бећковића. То би за ученике могло бити инспиративно, као што би добро било да се одржи и један научни скуп који би се бавио језиком Матије Бећковића. Бећковићево дело за такав приступ нуди богат језички материјал.

\section{ЛИТЕРАТУРА}

Андрић 2009: М. Андрић, Крила плаве песме - читанка за 6. разред основне школе, Београд: Завод за уџбенике.

Антологија 2009: Антологија Бећковић (избор и предговор

Селимир Радуловић), Нови Сад, Orpheus-Православна реч. Бабић 2012: Д. Бабић, Читанка за први разред средње школе, Београд: БИГЗ.

Бајић и Мркаљ 2006: Љ. Бајић, 3. Мркаљ, Читанка за 8. разред основне школе, Београд: Завод за уџбенике.

Бајић и др. 2016: Љ. Бајић, М. Павловић и 3. Мркаљ, Читанка Уибеник за четврти разред гимназија и средюих стручних школа, Београд: Klett.

Бећковић 2009: М. Бећковић, Послушаюа, Нолит-Графампромет, Београд-Рума.

15 Реч је о беседи коју је М. Бећковић одржао у априлу и мају 1988. године Србима у Северној Америци приликом прикупљања средстава за наставак изградње Храма Светог Саве на Врачару. Ова беседа је објављена више пута и цитирана у многим антологијама, уџбеницима и приручницима. 
Бећковић 2018: М. Бећковић, 100 мојих портрета, Београд: Вечерње новости.

Брборић 2018: В. Брборић, „Објашњење непознатих речи при обради књижевног текста", у: Љ. Бајић и др. (ред.) Актуелни теоријско-методолочки проблеми проучавана и наставе словенских језика, книжевности и култура, Београд: Филолошки факултет, 42-57.

Илић 1997: П. Илић, Српски језик и книжевност у наставној теорији и пракси - методика наставе, Нови Сад: Прометеј.

Јовановић 2015: А. Јовановић, „Бранко Ћопић - школски писац”, у: Иновације у настави, XXVIII, 2015/4, Београд: Учитељски факултет, 70-75.

Маринковић 2003: С. Маринковић, Методика креативне наставе српског језика и књижевности, Београд: Креативни центар.

Милатовић 2011: В. Милатовић, Методика наставе српског језика и кюижевности у разредној настави, Београд: Учитељски факултет.

Милић и Вучић 2016: Б. Милић и К. Вучић, Читанка са книжевнотеоријским појмовима за I разред гимназија и средюих стручних школа, Београд: Завод за уџбенике.

Несторовић и Грушановић 2016: 3. Несторовић и 3. Грушановић, Речи мудрости - читанка за 8. разред основне школе, Београд: Klett.

Николић 1992: М. Николић, Методика наставе српског језика и књижевности, Београд: Завод за уџбенике и наставна средства.

Николић и Милић 2003: Љ. Николић и Б. Милић, Читанка са књижевнотеоријским појмовима за І разред средне школе, Београд: Завод за уџбенике.

Николић и Милић 2016: Љ. Николић и Б. Милић, Читанка са књижевнотеоријским појмовима за IV разред средюе школе, Београд: Завод за уџбенике.

Павловић 2008: М. Павловић, Припремане наставника и ученика за тумачеюе кюижевних дела, Београд: Завод за уџбенике. 
Петровић и др. 2016: П. Петровић, М. Ђурић, Б. Сувајџић и Н. Станковић Шошо, Читанка за четврти разред гимназија и средюих стручних школа, Београд: Логос.

Станковић Шошо 2016: Н. Станковић Шошо, Уметност речи

- Читанка за осми разред основне школе, Београд: Логос.

Veljko Ž. Brborić

\section{MATIJA BEĆKOVIĆ IN THE CURRICULA AND THE TEXTBOOKS FOR THE PRIMARY AND SECONDARY SCHOOL}

The article talks about the work of Matija Bećković in the teaching process. An insight into the current curricula for elementary and secondary school was made and the presence of Bećković's work in the teaching process was determined. At the same time, the textbooks for the primary and secondary school were analyzed, so one can see what they bring and what our students are asked for when analysing the Bećkovićs work. So, the insight into textbook literature was made and the selection of the work that is being taught in our education was determined. In our opinion, this was sufficient to make the appropriate conclusions about the place and role of Matija Bećković in our educational system, ie. about the access of the textbook literature to the work of the famous poet.

Key words: Matija Bećković, curricula, textbooks and manuals, primary school, secondary school. 